\title{
PENDIDIKAN AGAMA ISLAM DALAM LANSKAP POST TRADISIONALISME ISLAM
}

\author{
Ed Susanto*
}

\begin{abstract}
A bstract: This paper is interestedin exploningthemost reent ament of thaught bdonging to theyaunger generation of Indonesian intelligentsia. This ament of thanght is known by many as post-traditionalism Whiledisaussingsome of itsmost ndabletraits, this paper tries to show that theschod of thangt - while bingintelletual and disarsive is also concemed with thestatef educationin the cantry. Thepaper argues first andforemost that theadvent of this shod was dueto thepoor quality of religias discoursein the country. By mans of citical approah and "letist" epistemlogy, this grap tries to subvet theexistingdiscaurses, whichit considasimderant. Sincetheseimdevant dotrines wereencapsulatedin theedurational institutions, the practical and strategic nay to dismantle these dotrines is by deconstructing their edurational system on the one hand, and by reeonstruting the new one, the one that reflets the universal and humanitarian values of Islamsuch tderanceand undastanding Keywords: IstamicPost-traditionalism education, amialum
\end{abstract}

\section{Pendahuluan}

D alam konteks diskursus Islam Indonesia, tradisionalisme Islam diidentifikasi sebagai paham yang, petama, sangat terikat dengan pemikiran Islam tradisional, yaitu pemikiran Islam yang masih terikat kuat dengan pikiran ulama fiqih, hadith, tasawuf, tafsir dan tauhid yang hidup antara abad ke tujuh hingga abad ke tiga belas ${ }^{1}$. Kedua, sebagian besar mereka tinggal di pedesaan dengan pesantren sebagai basis pendidikannya. Pada mulanya mereka menjadi kelompok eksklusif, cenderung mengabaikan masalah dunia karena keterlibatannya dalam dunia sufisme dan tarekat bertahan terhadap arus modernisasi dan arus pemikiran santri kota, cenderung mempertahankan apa yang mereka miliki dan ketundukan kepada kyai yang hampir-hampir tanpa batas. Ketiga, keterikatan terhadap paham Ahl al-Sumah wa al-Jama'ah yang dipahami secara khusus.

D engan karakter demikian, tradisionalisme Islam menjadi sasaran kritik gerakan modernisme Islam ${ }^{2}$ yang menolak sama sekali produk-produk intelektual yang menjadi landasan konstruksi tradisionalisme, sehingga-sampai tahapan tertentu-tradisi pemikiran

\footnotetext{
*Sekolah Tinggi Agama Islam (STAIN) Pamekasan.

${ }^{1}$ Kaum tradisionalis lebih senang mengikuti pendapat ulama-ulama besar di masa silam daripada mengambil kesimpulan sendiri berdasar al-Q ur'an dan hadith. Lihat Z amakhsyari D hofier, Tradis Pesantren: Studi tentang PandanganHidupKyai (Jakarta: LP3E S, 1982), 1.

${ }^{2}$ Modemisme dalam bahasa Arab sering diistilahkan dengan tajididyang artinya pembaruan. D alam konteks gerakan, kata pembaruan mengacu pada gerakan pemurnian yang berlangsung sebelum abad ke-19. Sedangkan modernisme digunakan untuk menjelaskan gerakan pembaruan yang muncul sejak abad ke-19 yang bertujuan untuk menyesuaikan ajaran Islam dengan pemikiran modern. D engan demikian, gerakan modernisme Islam dapat dipahami sebagai gerakan yang muncul pada periode sejarah Islam modem dengan mengadaptasi ajaran Islam kepada pemikiran dan kelembagaan modern. D i Indonesia, modernisme Islam berawal dari pembaruan pemikiran keagamaan (teologi), kelembagaan atau institusi, aspek sosial, pendidikan dan politik. Lihat Nia Kurnia dan Amelia Fauzia, "G erakan Modernisme," dalam ed. Taufik Abdullah et al., Ensiklopedi TematisDunia Isam(Asia Tenggara), jil. 5 (Jakarta: Ichtiar Baru Van Hoeve, 2003), 349-350. D alam bahasa Fazlur Rahman, gerakan pemikiran keagamaan modemisme ini disebut dengan istilah modernisme Islam klasik.
} 
klasik ditinggalkan, dan yang dominan adalah keterpesonaan terhadap berbagai aliran pemikiran Barat. Tendensi kaum modernis yang menolak produk dialektika Islam dengan tradisi lokal belakangan ini mengalami titik jenuh yang sebabnya antara lain karena sempitnya wahana intelektual yang hanya berorientasi pada al-Qur'an dan Sunnah ${ }^{3}$ serta irrelevansi yang semakin nyata-kentara dengan kultur keislaman di Indonesia.

D alam konteks demikian, pada pertengahan tahun 1990-an berkembang wacana pemikiran keislaman yang kembali menghargai khazanah pemikiran Islam klasik. Mula-mula yang menjadi rujukan arus baru dinamika pemikiran keislaman ini adalah pemikiran Fazlur Rahman ${ }^{4}$ yang diidentifikasi sebagai nœomodemisme Islam, yang berusaha mencari sintesis progresif dari rasionalitas modernis dengan tradisi Islam klasik.

Meskipun neo-modernisme berusaha untuk memadukan modernisme dengan tradisionalisme, namun-oleh kalangan tertentu-dinilai gagal keluar dari hegemoni modernisme dan menjadikan tradisionalisme sekadar ornamen sejarah dan bukan spirit transformasi sosial. ${ }^{6}$ Dalam konteks demikian, lahir genrebaru pemikiran Islam yakni post tradisionalisme Islam ${ }^{7}$ yang secara teoretik berusaha menjadikan unsur tradisional tidak sekadar sebagai ornamen sejarah dan menjadikan tradisionalisme sebagai basis untuk melakukan transformasi sosial. ${ }^{8}$

Untuk dapat memelihara dan melestarikan semangat post tradisionalisme Islam, kalangan ini tentu memiliki perspektif transformasi keilmuan tersendiri, terutama dalam mengemas format pemahaman pendidikan agama Islam sebagai wahana utama dalam mentransformasikan nilai-nilai keislaman ala post-tradisionalisme Islam yang mungkin saja sangat berbeda-atau berbeda sedikit saja, atau jika tidak, mungkin sama-dengan format pemahaman pendidikan agama Islam kalangan tradisionalisme klasik, revivalis, modernisme klasik atau pun yang lainnya.

${ }^{3}$ Azyumardi Azra menyebutkan bahwa titik jenuh itu terjadi karena mengalami keterputusan intelektual karena membuang khazanah intelektual yang muncul pada periode taqlid Khazanah intelektual kaum modernis- dalam pandangan Azra-terbatas pada generasi sahabat (salaf al-salih), melompat ke (sedikit) Ibn Taymiyah, kemudian mengadopsi pemikiran pembaru mulai abad ke-17 seperti Shah WaliæAllah, Muhł̇mmad bin 'Abd al-Wahhab, Jamaßal-D in al-Afghani> Muhłmmmad 'Abduh dan Rashid Ridł̨> Lihat Azyumardi Azra, "Mengkaji Ulang Modernisme Muhammadiyah," Kompas, 9 Nopember 1990.

${ }^{4}$ D alam perspektif Fazlur Rahman, meskipun semangat modernisme klasik telah benar, namun mereka setidaknya memiliki dua kelemahan mendasar. Petama, tidak mengurai secara tuntas metode yang secara semi implisit terletak dalam menangani masalah-masalah khusus dan implikasi prinsip-prinsip dasarnya. Keetua, tidak dapat dihindari mereka mengesankan sebagai agen westernisasi. Lihat Rumadi, Post TradisionalismeIdam Wacama IntdkktualismedalamKommitasNU (Jakarta: Ditjen D iktis, 2007), 14.

${ }^{5}$ Bahasan lebih jauh mengenai neo-modernisme Islam periksa Fazlur Rahman, NeøModamismeIdam Medodedan Altematif, ed. Taufik Adnan Amal (Bandung: Mizan, 1989). Lihat juga G reg Barton, Gagasan IsamLibeal di Indonesia: PemikiranNeoModernismeNurcholishMadid, DjdhanEffend, AhmadWahibdanAbdurrahman Wahid, terj. Nanang Tahqiq (Jakarta: Paramadina, 1999).

${ }^{6}$ Rumadi, Post Tradisionalisme, 15.

${ }^{7} \mathrm{D}$ alam diskursus akademik, istilah post tradisionalismeini dipandang tidak lazim, karena belum dijumpai dalam kamus, juga belum ada ilmuwan yang menggunakan istilah ini. Bahkan menurut K hamami Zada, justru lahir di Indonesia, yang disuarakan oleh gerakan kritis generasi muda dari kalangan Islam tradisional. Periksa K hamami Zada, "Mencari Wajah Post Tradisionalisme Islam”, Tashminul Afkar, No. 9 (2000), 2-5.

${ }^{8}$ Post-Tradisionalisme Islam ini, sebagaimana diidentifikasi dalam disertasi Rumadi, tumbuh subur pada pemahaman keagamaan generasi muda kritis kalangan Nahdlatul Ulama (NU), yang pada satu sisi berusaha agar akses mereka terhadap dinamika kehidupan modern terbuka lebar, namun pada sisi lain, mereka tetap berobsesi untuk tidak tercerabut pada dinamika akar tradisionalitasnya 


\section{Karakter Dasar Post Tradisionalisme Islam}

Post-tradisionalisme Islam diakui sebagai tradisi pemikiran Islam yang khas Indonesia, khususnya dalam komunitas Nahdlatul Ulama (NU). D alam konteks ini dapat dinyatakan bahwa post-tradisionalisme merupakan konstruk intelektualisme yang berpijak pada (dan dari) kebudayaan lokal Indonesia, bukan tekanan dari luar (proyek "asing”) yang berinterakasi secara terbuka dengan berbagai jenis elemen masyarakat. Post-tradisionalisme Islam tidak hanya mengakomodasi pemikiran liberal dan radikal ${ }^{9}$ tetapi juga tradisi pemikiran sosialisMarxis, post-strukturalis, postmodernis, gerakan feminisme, dan divi sociey. Secara khusus disebutkan bahwa metodologi pemikiran dan politik post-tradisionalisme Islam dikonstruksi melalui pemikiran Muhammad Abed al-Jabiri. Hal ini menunjukkan bahwa pemikiran alJabiri melalui proyek Naqdal-Aqd al-'Arabimempunyai posisi yang sangat penting, di samping tokoh-tokoh yang telah disebutkan. ${ }^{10}$

Lebih jauh, dapat ditegaskan bahwa spirit aktivitas intelektual komunitas posttradisionalisme Islam adalah semangat untuk terus-menerus mempertanyakan kemapanan doktrin dan tradisi berdasar nilai-nilai etis yang diperoleh setelah bergumul dengan berbagai tradisi keilmuan, baik melalui kajian, penelitian, maupun penerbitan buku dan jurnal. Berbagai bentuk penafsiran atas teks suci, tradisi, dan ideologi yang tidak mengabdi kepada kepentingan kemanusiaan, apalagi menistakan kemanusiaan digugat keabsahannya, baik pada tingkat relevansi maupun kemungkinan adanya manipulasi dan politisasi. ${ }^{11}$

Satu hal yang perlu dicatat bahwa gerakan intelektual post tradisionalisme Islam berangkat dari kesadaran untuk melakukan revitalisasi tradisi, yaitu sebuah upaya untuk menjadikan tradisi (turath) sebagai basis untuk melakukan transformasi. D ari sinilah komunitas

\footnotetext{
9Seperti pemikiran Hassan Hanafi, Mahmoud Mohammed Thaha, Abdullahi Ahmed al-Na'im, Arkoun, Nasr Hamid Abu Zayd, Mohammed Syahrour dan Khalil Abd al-Karim.

${ }^{10}$ Terdapat argumentasi yang dapat digunakan untuk mempertanggungjawabkan hal ini: Pertama-tama Muhammad Abid al-Jabiri dikenal dengan proyek metodologis "Kritik Nalar Arab"-nya. Ada dua hal yang ditawarkan proyek kritik tersebut: kritik nalar epistemologis dan kritik nalar politik. Kritik nalar epistemologis disebut juga "nalar spekulatif " , mengambil bentuk arkeologi yang meneliti persoalan cara-cara dan mekanis mereproduksi pengetahuan yang berlaku di kalangan umat Islam hingga kini. Yang ditelaah misalnya bagaimana uslibal-fighmembentuk pola pikir umat Islam dengan metodologi qiyas nya (analogi) yang cenderung mengarah pada sakralisasi, bukan hanya pada soal hukum-hukum agama, tapi juga dalam segenap spektrum kebudayaan manusia, mulai dari bahasa, sastra, teologi, filsafat, hingga politik (misalnya kalau berbicara tentang sosialisme yang "Islami"). Sementara kritik nalar politik, yang dikenal dalam kategori "nalar praktis", menekankan sebuah praksis, dengan fokus kritik kepada cara-cara berkuasa dan menguasai. Yang dibedah misalnya adalah persoalan keterkaitan munculnya disiplin syassh shar'iyyah atau fiqh al-siyasah dengan strategi militeristik kekuasaan khalifah untuk menundukkan masyarakatnya". A hmad Baso, "Pengantar penerjemah: Post Tradisionalisme sebagai Kritik Islam, Kontribusi Metodologis Kritik Nalar Muhammed Abed al-Jabiri," dalam Muhammad Abed al-Jabiri, Post Tradisionalisme Isam(Yogyakarta: LKiS, 2000), 33.

${ }^{11}$ Atas dasar itu mereka selalu menaruh curiga atas berbagai narasi besar, baik yang diproduksi melalui tradisi, ideologi, maupun teks suci. Bagi komunitas ini, narasi besar hanya ingin melakukan monopoli atas kebenaran. Ideologi-ideologi besar dunia, bahkam juga tafsir dominan atas agama sebenamya juga ingin memonopoli kebenaran. A tas dasar itu, mereka menolak segala bentuk penunggalan itu, karena "penunggalan" tidak akan mampu menyelesaikan persoalan. Sampai di sini, catatan Marzuki Wahid atas "Manifesto Perang Kebudayaan" Kaum Muda NU 2015 di Malang 2001 sangat menarik untuk disimak. Dalam dokumen tersebut, disebutkan target gerakan kaum muda NU antara lain: 1) rebut kepemimpinan moral dan intelektual di segala lini gerakan kemasyarakatan, 2) konsisten di jalur politik ekstra parlementer berbasis multikulturalisme dengan tetap menghormati "orang lain" sebagai warga negara, lengkap dengan tradisi dan kebudayaannya sendiri, dan 3) menyiapkan secara serius paradigma eonomical soidydan membangun basis ekonomi mandiri demi penciptaan divil sociey. Lihat Marzuki Wahid, "Post-Tradisionalisme Islam," 17.
} 
post-tradisionalisme Islam bertemu dengan pemikir Arab modern seperti Muhammad Abed al-Jabiri dan Hassan Hanafi yang mempunyai apresiasi tinggi atas tradisi sebagai basis transformasi.

Komunitas post-tradisionalisme Islam mencoba untuk melihat tradisi secara kritis, historis, dan objektif. ${ }^{12}$ D alam konteks demikian, wacana post-tradisionalisme Islam sangat dipengaruhi oleh semangat perkembangan pemikiran Arab modern yang diadopsi sebagai optik untuk membaca tradisi NU dan pemikiran Islam. ${ }^{13}$

D engan menggunakan optik tradisi sebagaimana telah diuraikan, maka problem posttradisionalisme Islam sebenarnya adalah bagaimana melakukan pembaharuan pemikiran keagamaan yang harus mengkritisi tradisi di satu pihak, namun pada pihak lain memiliki kebutuhan untuk "tergantung" pada tradisi sebagai basis transformasi. ${ }^{14}$

\section{Pendidikan Agama Islam dalam Perspektif Post-Tradisionalisme}

Islam, bagi post-tradisionalisme diposisikan sebagai nilai yang bersifat sakral-universal. Namun ketika nilai-nilai Islam itu bersentuhan dengan realitas sosial budaya, maka perwujudan nilai-nilai yang kemudian menjadi institusi-suatu nilai yang telah melembagatersebut menjadi bersifat partikular-lokal-profan. D engan pemahaman demikian, posttradisionalisme sesungguhnya telah melakukan "kritik nalar" terhadap konstruksi pemahaman keislaman yang selama ini ada dan berkembang dominan dalam kehidupan umat Islam.

Sehubungan dengan kritik nalar, terdapat dua istilah yang dirangkaikan dengan istilah tersebut, yakni Kritik Nalar Islam yang merupakan produk pemikiran Mohamed Arkoun dan K ritik Nalar A rab, yang ditelorkan oleh Muhammad Abed al-Jabiri. ${ }^{15}$ Kedua kritik nalar tersebut, sekalipun mempunyai konsentrasi dan pernik pemikiran yang berbeda, secara garis

\footnotetext{
${ }^{12}$ Mereka tidak segan-segan mengkritik tradisinya, bahkan doktrin keagamaan yang selama ini diterima secara taken for granted. D oktrin teologi Aswaja yang bertahun-tahun mulai mereka pertanyakan, baik doktrinnya itu sendiri maupun kemampuan dan relevansinya dengan perkembangan zaman, sehingga digagas teologi kemanusiaan yang lebih transformatif. D alam bidang fikih mereka juga menggagas kontekstualisasi fikih dan kitab kuning, sehingga melahirkan fikih rakyat, fikih perburuan, fikih ijtima (sosial), fikih politik yang berorientasi rakyat, dan sebagainya.

${ }^{13}$ Semangat yang diusung adalah kesadaran kritis untuk mempertanyakan tradisi dan pengetahuan. Semangat yang demikian akan sangat mudah dicarikan referensi historisnya, seperti Ibn K haldun melalui al-Muqaddimah yang merasa sangat prihatin dengan penulisan sejarah yang telah kehilangan objektivitas, bahkan sejarah ditulis secara kronologis sehingga kehilangan aspek sosiologisnya. D emikian juga yang dilakukan Imam al-Ghazaki> ketika mengkritik filsafat Ibn Sina dalam karyanya Tahafit al-Falasiáh (Kerancuan [pikiran] para Filosof), Ibn Rushd ketika mengkritisi karya al-G hazalizlalam bukunya Tahafutal-Tahafit(Kerancuan [buku] Kerancuan para Filosof), dan seterusnya.

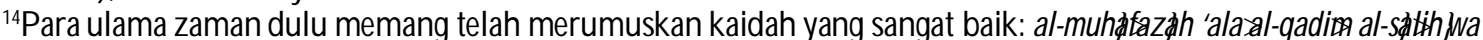
al-akhdhbi al-jadidal-aslab(memelihara tradisi lama yang baik, dan mengadopsi tradisi baru yang lebih baik), namun problemnya ternyata tidak sesederhana rumusan kaidah tersebut. Kerumitan problem itu terjadi karena adanya tarik-menarik yang terkadang sangat kuat antara "modemisme" dan "tradisionalisme" yang secara natural memang sulit disandingkan.

${ }^{15}$ Peneliti tidak tahu persis, apakah di balik distingsi istilah terdapat semacam perbedaan kekuatan ideologi yang menggerakkannya, atau itu hanya sekedar perbedaan istilah yang sebenarnya memiliki basis ontologis yang sama. D alam kaitan ini, penjelasan Ahmad Baso cukup membantu mengklarifikasi masalah tersebut, sekalipun belum cukup memuaskan. Menurutnya, Arkoun menggunakan kritik nalar Islam untuk memperluas cakupan kritiknya hingga sampai pada tradisi pemikiran non bahasa Arab. Sedangkan kritik nalar Arab-nya al-Jabiri untuk membatasi jangkauan kritiknya pada tradisi pemikiran yang menggunakan bahasa A rab dalam geografis kultur tertentu. Kritik nalar Arab tidak diproyeksikan untuk membangun sebuah ilmu baru, tetapi lebih dititikberatkan pada kerangka dan mekanisme berpikir yang mendominasi kebudayaan Arab dalam kurun waktu tertentu. Sedangkan
} 
besar memiliki agenda yang sama, yaitu agenda untuk melepaskan diri dari keterbelengguan tradisi dan teks mengingat keterbelengguan kepada kedua hal tersebut (tradisi dan teks) yang selama ini menjadi sumber kebekuan pemikiran Islam.

K ritik nalar dalam istilah filsafat ilmu diidentifikasi sebagai kritik epistemologi, ${ }^{16}$ yaitu kritik terhadap metodologi yang melahirkan sebuah ilmu. Oleh karena itu, munculnya kritik nalar pada kalangan post-tradisionalisme Islam merupakan respon ketidakpuasan yang dirasakan kalangan ini atas metodologi kajian Islam yang berkembang selama ini. Istilah kritik epistemologi dalam konteks ini ditujukan pada seluruh bangunan keilmuan Islam yang dilihat sebagai produk sejarah pemikiran keagamaan yang dianggap relatif. Analisis epistemologis dengan mengedepankan dimensi kritik harus diterapkan kepada teks-sakral maupun profan, historis maupun filosofis, teologis maupun yuridis, sosiologis ataupun antropologis-terlepas dari kedudukannya atau status kognitifnya dalam sebuah tradisi keyakinan, pemikiran maupun pemahaman. ${ }^{17} \mathrm{D}$ engan demikian, menjadi jelas posttradisionalisme Islam mengedepankan dimensi kritik nalar (naqd al-'ad) dalam memandang studi Islam dengan segala derivasinya.

Implikasi dari penggunaan kritik nalar dengan topangan pemikiran epistemologi "anti kemapanan" dari para filosof di atas menjadi wajar, lumrah-bahkan harus-jika pemikiran post-tradisionalisme Islam mencurigai setiap produk pemikiran serta menelisik kepentingankepentingan di balik sebuah pemikiran. D alam konteks demikian, kritik nalar pada dasarnya merupakan perlawanan terhadap kuasa pengetahuan yang menyelinap di alam bawah sadar dan menghilangkan kesadaran bahwa setiap pengetahuan yang seolah netral, esensialis dan substansialis sebenamya mengandung kepentingan-kepentingan Dalam konteks ini, tradisi pada satu sisi dapat menjadi objek kritisisme, namun pada saat lain dapat menjadi subjek dan alat kritisisme.

Kritisisme mengandaikan dua hal sekaligus, petama, dekonstruksi, yaitu melakukan pemutusan hubungan epistemologis terhadap segala otoritas yang membentuk tradisi pengetahuan, dalam mana hal ini dilakukan dengan merombak sistem relasi yang baku dan beku, menjadi sistem relasi yang cair dan berubah-ubah, dari yang mutlak menjadi relatif, dari ahistoris menjadi historis, kedua, rekonstruksi yaitu sebuah pertanggungjawaban untuk memberi sisi-sisi masuk akal (reasanable) dalam segenap persoalan. ${ }^{18} \mathrm{D}$ alam konteks dekonstruksi dan rekonstruksi inilah, kesadaran bahwa setiap tradisi adalah dibentuk (invented) dan distrukturkan (constructeel) menjadi relevan dan penting. ${ }^{19}$

kritik nalar Islam Arkoun lebih ditujukan kepada konsep-konsep seperti ortodoksi, wahyu, mitos, imaginasi simbol dan seterusnya. Lihat Ahmad Baso, "Pengantar Penerjemah Post Tradisionalisme sebagai K ritik Islam: Kontribusi Metodologis Kritik Nalar Muhammed Abed al-Jabiri," dalam Muhammad Abed al-Jabiri, Post TradsionalismeIdam(Yogyakarta: LKiS, 2000), xxix-xxx.

${ }^{16}$ Epistemologi merupakan salah satu cabang filsafat yang berbicara tentang metode untuk memperoleh dan menyusun struktur ilmu, sehingga epistemologi berbicara tentang struktur nalar yang membentuk ilmu.

${ }^{17}$ Mohammed Arkoun, "K ritik Konsep Reformasi Islam," dalam Abdullahi Ahmed an-Na'im et al., Dekonstruksi Syaar’ahII: Kritik KonsepdanPexjdajahan Lain, terj. Farid Wajidi (Yogyakarta: LKiS, 1996), 13.

${ }^{18}$ Rumadi, Post TradisionalismeIsam 196.

${ }^{19} \mathrm{D}$ alam konteks pemikiran Islam, kita tidak bisa dengan mata telanjang merujuk kepada tradisi Nabi Muhammad saw., termasuk dengan kembali kepada al-Q ur'an dan hadith dan segala yang terjadi pada periode kodifikasi dan pembakuan ('ast' al-tadvin) dengan tanpa melalui optik atau sudut pandang yang dibentuk pada 'as' al-tadwin tersebut. Bukankah sejarah Nabi Muhammad baru dapat diketahui setelah membaca buku-buku sejarah Nabi. Bukankah pemahaman terhadap al-Q ur'an juga harus melalui kitab-kitab tafsir otoritatif? Sejak itu berarti ada 
Kesadaran demikian, oleh kalangan post-tradisionalisme, berusaha untuk ditubuhkan (dikonkretisasi) melalui basis kurikulum pendidikan agama Islam dalam konstruksi kurikulum yang sama sekali lain (beda) dengan konstruksi pendidikan agama Islam yang selama ini dikembangkan di lembaga-lembaga pendidikan formal resmi selama ini. Perbedaan tersebut dapat disimak pada konstruksi kurikulum yang digagas oleh LKiS, P3M dan D esantara sebagai eksponen utama post-tradisionalisme Islam.

LKiS sejak tahun 1997 sampai sekarang menyelenggarakan suatu program yang diidentifikasi dengan "Belajar Bersama Islam Transformatif dan Toleran." Program ini merupakan program pendidikan alternatif bagi kalangan anak muda kritis sebagai salah satu upaya penguatan divil soiety dengan mengembangkan wacana kritisisme baik kepada teks keagamaan, tradisi dan sebagainya. D engan model belajar bersama ini, terbentuk suatu jaringan kaum intelektual muda progresif yang menjadikan gagasan dan wawasan Islam transformatif dan toleran menjadi tersebar luas ke berbagai daerah dan kampus-kampus. Sedangkan P3M mengembangkan wacana kerakyatan dengan menggunakan tradisi keagamaan sebagai basis transformasinya. Tema-tema yang diangkat misalnya fiqh al-nisa', figh al-siyasah, Islam dan demokrasi, hłlaqah ideologi-ideologi besar dunia, demokrasi pesantren dan yang paling populer kini adalah program Islam emansipatoris. ${ }^{20}$

Komunitas D esantara menyelenggarakan paket belajar dengan nama Madrasah Emansipatoris dengan konstruksi kurikulum sebagai berikut. ${ }^{21}$

1. Kelas "kritik wacana agama":

a. Overviewtentang agama, meliputi (a) konstruk-konstruk tentang agama, (b) agama dan konstruk kebudayaan, (c) Agama: kekuasaan dan altural aitizenship(d) historisitas teks suci dan tafsir.

b. Pembentukan teks-teks agama dan kebenaran agama

c. Agama sebagai resistensi, meliputi (a) siasat-siasat agama lokal, (b) NU sebagai agama "Post-kolonial," (c) agama dan multikulturalisme.

2. Kelas kritik wacana gender:

a. Evaluasi dan reiewtentang perempuan dan modernitas, meliputi (a) gender dalam

otoritas yang turut bergerak dan menggerakkan pengetahuan. Ketika berbicara tentang fikih misalnya, orang tidak mungkin melepaskan dari otoritas Imam Hąnafi>Malik, Shafi' $1>$ A hmad bin $\mathrm{H}$ ąnbal dan seterusnya. D emikian juga yang berkaitan dengan al-Q ur'an tidak dapat semata-mata dipandang sebagai sesuatu yang transenden tanpa campur tangan sejarah dan budaya, tetapi juga merupakan konstruk yang dibentuk tradisi dan budaya. Adanya unsur tradisi dan budaya dalam al-Qur'an tidak bisa selalu diartikan sebagai tindakan yang merendahkan alQ ur'an karena wahyu jika sudah bersentuhan dengan sesuatu di luar Tuhan, maka pada saat yang sama ia sudah menjadi historis.

${ }^{20}$ Program Islam emansipatoris mempunyai tiga garapan utama, yaitu; 1) pendidikan, 2) talk show di radio dan televisi, dan (3) penerbitan bulletin Jum'at al-Nadhar dan website. Program Islam emansipatoris ini sangat dipengaruhi oleh teori-teori kritis ilmu sosial mazhab Frankfrut, sehingga dalam programnya, eksponen Islam emansipatoris mengusung obsesi mendekatkan agama dengan problem kemanusiaan melalui tiga hal. Petama, Islam emansipatoris ingin memberikan perspektif baru terhadap teks, yakni mencoba melihat teks dari kacamata konteks dan problem kemanusiaan, karena teks lahir dari konteks dan sosio-kultur masyarakat pada zamannya. Kedua, Islam emansipatoris menempatkan manusia sebagai subjek penafsiran keagamaan. Hal ini dalam rangka memperpendek jarak yang terlalu jauh antara teks dan realitas, sehingga teks tidak kehilangan élan transformatifnya. Ketiga, Islam emansipatoris mempunyai concem kepada persoalan kemanusiaan ketimbang persoalan teologis. Lihat Profil Jaringan Islam Emansipatoris.

${ }^{21}$ Booklet, "Madrasah Emansipatoris: A gama, G ender dan Kebudayaan," Desantara Institutefor Cultural Studies, 2002. 
perspektif altural studies, (b) konstruk agama tentang perempuan, (c) konstruk kapital tentang perempuan (d) konstruk negara tentang perempuan, (e) sejarah pemikiran dan gerakan perempuan di Indonesia.

- Perempuan dan multikulturalisme, meliputi (a) perempuan dan seni tradisi, (b) perempuan dan ritus-ritus tradisional, (c) perempuan dan kegiatan ekonomi

- Perempuan dan resistensi

3. Kelas kritik wacana kebudayaan, meliputi:

- Konstruk tentang kebudayaan, meliputi (a) teori-teori kebudayaan, (b) konstruk tentang kebudayaan nasional. (c) aktor-aktor konstruk keagamaan (pasar, agama resmi dan negara) (d) strategi, negosiasi dan resistensi budaya

- Konsep-konsep altural studies Konstruk, resistensi, relasi kuasa dan kontestasi

- Resistensi budaya dan metodologi altural sudies (etnografi dan semiotika).

D engan demikian, dapat disimpulkan bahwa agenda-agenda intelektual yang dirumuskan dalam silabus pendidikan komunitas post-tradisionalisme Islam adalah "wacana subversif", yang sangat diilhami oleh denyut post-modernisme yang menolak adanya sentralisme (deeenteing dan segala bentuk hegemoni. ${ }^{22}$ D engan semangat "subversi akademik" dan kritik nalar inilah, kalangan post-tradisionalisme melancarkan pembaruan pemikirannya yang sangat menentukan terhadap konstruksi dan muatan materi pendidikan agama Islam yang meliputi pemaknaan baru Aswaja, Islam dan politik kewarganegaraan, Islam dan feminisme, dialog agama untuk keadilan, Islam dan budaya lokal serta pembaruan fikih dan canaid al-usjle: ${ }^{23}$

Pemaknaan baru Aswaja (Ahl al-Sunnahwaal-Jama'gh) dilakukan melalui pembongkaran sisi metodologi berpikirnya (manhaj al-fikr) setelah melalui penelusuran sejarah sehingga ditemukan bahwa Aswaja merupakan manhaj al-fikryang memegang prinsip moderat (tawassit), seimbang (taważun), dan berkeadilan (i'tidal), sehingga dapat mengantarkan pada sikap keberagamaan non ekstrem (ghayr al-tatamuf). ${ }^{24}$ Tentang problem Islam dan politik kewarganegaraan, post-tradisionalisme Islam berusaha melalukan penguatan dan pemberdayaan diil soidymelalui penegasan bahwa persoalan politik dipandang bukan sebagai masalah sekuler melainkan merupakan salah satu persoalan pokok agama (as) min uslil aldib), dan bukan sebagai salah satu cabang fikih (far' min funu'sal-figh).

Adapun tentang Islam dan feminisme, post-tradisionalisme mengkritisi ajaran yang dipahami selama ini. Dalam perspektifnya, agama sering kali dijadikan sebagai alasan dalam proses subordinasi kaum perempuan dalam pelbagai segi kehidupan. Penyifatan-penyifatan pejaratif terkadang dirujukkan kepada perempuan oleh tafsir agama yang membentang dari persoalan seksualitas sampai peran politik perempuan. ${ }^{25}$ Post-tradisionalisme Islam

${ }^{22}$ Bahasan tentang kritik post modernisme terhadap hegemoni dan metanarasi modernisme lihat Edi Susanto, "Postmodernisme: Kritik atas Mła NarrativeE pistemologi Modernisme," al-Afkar Jumal Dialogis Ilmrilmu Ushuluddin, Ed. 3 (Juli-D esember 2003), 1-11.

${ }^{23}$ Rumadi, Post TradisionalismeIsam 231-310.

${ }^{24}$ Lihat Said Aqiel Siradj, "Latar Kultural dan Politik Kelahiran Aswaja," dalam ed. Imam Baehaqi, Kontrouesi Asuaja: Aula Perdbatandan Reinterpreas (Yogyakarta: LKiS, 2000), 4.

${ }^{25}$ Misalnya, dalam konsep hijab di mana tempat ideal perempuan adalah di rumah. D alam konsep imamah perempuan tidak boleh berpolitik. D alam hal waris, bagian perempuan separuh dari bagian laki-laki. Perempuan juga tidak boleh menjadi imam salat yang makmumnya adalah laki-laki. Ini hanya sekadar contoh bagaimana doktrin agama telah ikut berperan dalam penomorduaan kaum perempuan. 
menganggap doktrin dan tafsir agama semacam itu sangat merugikan dan mendiskreditkan perempuan, dan karenanya, sangat bertentangan dengan semangat dasar Islam yang mengakui kesetaraan dan persamaan antara laki-laki dan perempuan. Karena itu, post-tradisionalisme Islam mengintrodusir pentingnya dilakukan pembacaan ulang terhadap doktrin, pemikiran dan teks-teks keagamaan secara kritis.

Pandangan post-tradisionalisme Islam tentang dialog agama untuk keadilan juga sangat mendasar. Setiap manusia, dalam pandangan post-tradisionalisme Islam, memiliki hak asasi sama yang harus dihormati oleh semua orang. Islam diyakini sebagai agama yang menjamin penghormatan atas hak-hak dasar tersebut. Al-Q ur'an tidak pernah memberikan keterangan mengenai perlakuan diskriminatif terhadap non muslim. Sebaliknya, Islam menuntut agar umatnya saling mengenal, menghargai dan menjalin kerja sama.

Untuk mengatasi persoalan tersebut, ada beberapa agenda yang direkomendasikan post-tradisionalisme Islam. Petama, perlu ada reinterpretasi ajaran agama menuju sebuah teologi yang lebih toleran dan terbuka, mengingat pemahaman teologis mempunyai andil besar dalam menentukan model dan corak keberagamaan, ${ }^{26}$ keelua, perlu membuka forumforum dialog antara muslim dan non muslim dengan mengedepankan kejujuran, ketiga, penting adanya kerja sama riil dan intens antara muslim dan non muslim dalam kerja-kerja pelayanan publik, dan keempat, sistem politik dan produk hukum yang diskriminatif harus diubah menjadi toleran dan terbuka.

Pandangan post-tradisionalisme Islam tentang posisi Islam terhadap budaya lokal adalah adanya gagasan tentang pribumisasi Islam. Pribumisasi Islam berusaha untuk menjadikan agama (Islam) dan budaya lokal tidak saling mengalahkan melainkan mewujud dalam pola nalar religiositas yang tidak lagi mengambil bentuknya yang otentik dan murni (pure) dari agama dan berusaha menjadi jembatan yang selama ini memisahkan antara keduanya (agama dan budaya). ${ }^{27}$

Upaya pribumisasi Islam tersebut didasarkan pada logika bahwa dalam setiap universalisasi selalu berangkat dari sesuatu yang bersifat partikular. Proses universalisasi tersebut mengandaikan dua hal sekaligus: petama, proses distilasi dan abstraksi nilai-nilai abstrak yang bersifat universal dalam Islam, kedua, mengkonkretkan konteksnya kembali nilai-nilai tersebut dalam konteks kekinian. D engan demikian, terdapat tiga proses yang harus dilalui, yaitu: enbeedbed, disenbeedbed dan reembedbed ${ }^{28}$

\footnotetext{
${ }^{26}$ Pada tingkat praktik diskursif keagamaan, perlu dibaca kembali pengalaman kenabian Nabi Muhammad sebagai muslim di tengah beberapa ajaran (agama) yang sudah ada sebelumnya. Dalam hubungan ini, paling tidak, terdapat lima prinsip yang dapat diambil dari pengalaman Nabi Muhammad dalam mengelola kehidupan beragama yang dapat dicermati dari beberapa ayat al-Q ur'an. Petama, pluralitas, bahwa berbagai varian agama tetap diberi kebebasan hidup, bahkan para pemeluk agama dari berbagai varian agama tersebut diidentifikasi oleh $\mathrm{Nabi}$ Muhammad sebagai orang yang memiliki keyakinan sama dengan apa yang dibawanya. Kedua, inklusivitas, pengakuan adanya kebenaran di luar komunitas sendiri. Ketiga, identitas lokal menjadi ikon bagi suatu aspek identifikasi masyarakat. Tanpa lokalitas itu, bangsa Arab tidak akan menemukan harga diri. Kempat, visioner, yaitu membentuk masyarakat dengan moralitas dan semangat yang baru. Kdima, hegemoni dalam artian suatu bangsa (masyarakat) harus memiliki harga diri.

${ }^{27}$ Imdadun Rahmat, "Islam Pribumi: Mencari Wajah Islam Indonesia," Tashwirul Afkar, No. 14 (2003), 9.

${ }^{28}$ Posting di milis emansipatoris yahoo.com pada 11 Pebruari 2003. Ketiga proses tersebut dapat diilustrasikan sebagai: Islam datang ke tanah Arab, lekat dengan kultur Arab (embeement). Islam itu kemudian diambil dan dilepaskan unsur-unsur Arabnya untuk selanjutnya diambil inti sarinya (disenbedment), yang inti sari itu ditanam lagi ke dalam bumi kita sendiri (reembedment). D alam pandangan post-tradisionalisme Islam, universalisasi Islam
} 
Sedangkan pembaruan fikih dan qawałid al-usjlil diupayakan oleh kalangan posttradisionalisme Islam, karena fikih yang ada selama ini (fikih konvensional) dipandang bersifat eksklusif, rasial, patriarkhal, agraris tradisional dan fikih lokal Arab. ${ }^{29} \mathrm{~K}$ arena fikih didasarkan kepada sandaran logika berpikir tertentu, yakni usjli al-fiqh, maka kalangan posttradisionalisme Islam berupaya menawarkan pembaruan kaidah uskllal-fiqh sebagai alternatif dari kaidah uskli al-figh konvensional, misalnya al-'ibrah bi al-maqasid lałdi al-alfadh, ${ }^{30}$ jawaz

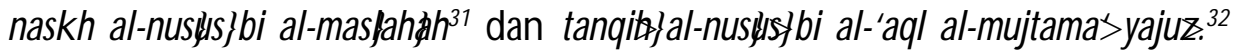

\section{Penutup}

D engan melihat gagasan-gagasan post-tradisionalisme Islam sebagaimana diajukan di atas, makajelas sangat dibutuhkan restruksturisasi paradigma filosofis dan muatan pendidikan agama Islam yang sudah berlangsung selama ini. Proyek pembaruan pemikiran Islam yang didengungkan oleh kalangan post-tradisionalisme Islam, sampai batasan tertentu, jelas merupakan masukan terhadap dekonstruksi-rekonstruksi paradigmatik dan muatan kurikulum pendidikan agama Islam yang selama ini telah dipraktikkan.

Secara pelan tetapi pasti, apa yang telah dicoba dengungkan oleh kalangan posttradisionalisme Islam dan kelompok pembaruan pemikiran Islam lainnya sesungguhnya mesti dipandang sebagai obat penawar terhadap "toksin" paradigma dan struktur muatan kurikulum pendidikan agama Islam yang sampai batas tertentu masih bercorak problem agraris

\footnotetext{
bisa diterima jika ia bergerak dalam kerangka siklus tersebut dan universalisasi itu ditolak jika universalisasi itu "loncat" dari Arab ke Jawa, Medan, Madura dan lainnya dengan tanpa melewati proses pelepasan unsur-unsur Arabnya.

${ }^{29}$ Bahasan elaboratif tentang sifat-sifat fikih konvensional tersebut periksa Rumadi, Post-TradsionalismeIdam 303307. Sifat eksklusivisme fikih konvensional misalnya terlihat pandangan fikih terhadap kaum non muslim yang selalu dipandang sebagai ancaman, sehingga mereka tidak bisa diposisikan setara dengan orang Islam. Rasialitas fikih konvensional misalnya terlihat dari perbedaan antara Imam Shafi i >yang berasal dari A rab dan Imam $\mathrm{H}$ фnafi> yang berasal dari Persia tentang bacaan surat al-Fatihăh. Imam Shafi'i imengharuskan Fatihłh berbahasa Arab ketika salat, sementara Hąnafi>Fatih $\not h$ boleh diucapkan dalam bahasa Persia bagi yang tidak dapat berbahasa Arab. Patriarkhialitas fikih konvensional terlihat dari ajaran fikih yang sangat menomorsatukan laki-laki dan meletakkan perempuan pada posisi subordinat. Adapun dimensi Agraris tradisional fikih konvensional terletak dalam topik masalah yang dikaji seperti tentang zakat yang didominasi oleh zakat hasil pertanian dan sama sekali tidak menyentuh masalah yang berkaitan dengan perkembangan bisnis mutakhir. Dimensi lokal Arab fikih konvensional sangat tampak pada penentuan kehalalan dan keharaman sesuatu sangatlah bersifat A rab sentris

${ }^{30}$ al-Tbrahbi al-macasidlałi al-alfaz/ artinya bahwa yang menjadi pegangan seorang Mujtahid dalam berintinbat\} hukum bukanlah huruf atau lafaz dalam al-Q ur'an maupun Sunnah, tetapi maqasidshar' 'ahyang dikandungnya. Cita-cita moral dan nilai etik dari al-Q ur'an harus lebih diutamakan dari pada ketentuan legal spesifiknya. Kaidah ini merupakan antitesis dari kaidah yang berbunyi al-'ibrahbi 'umumal-lafzlałs khushsal-sabab.

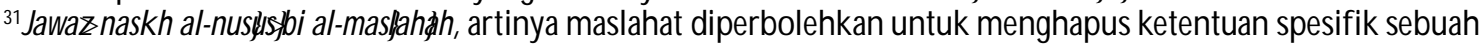
nas\$ Kaidah ini muncul dari asumsi bahwa shari'at Islam diturunkan tidak lain adalah untuk kemaslahatan kemanusiaan universal. Jadi, untuk mewujudkan kemaslahatan universal itu, ketentuan legal spesifik nas\$bisa diabaikan. Ketentuan legal spesifik nas\$dapat diabaikan karena maslahat merupakan spirit tertinggi nas\$sehingga maslahat dimungkinkan untuk beberapa ketentuan spesifik nassjjang dipandang tidak lagi relevan

${ }^{32}$ Tanqih al-nusksyldi al-'aql al-mjtama' yajuz, artinya akal publik (publicreason) mempunyai kewenangan untuk "mengamandemen" ketentuan dogmatik agama yang menyangkut masalah publik [baik dalam al-Qur'an maupun Sunnah]. Jika terjadi pertentangan antara akal publik dengan bunyi harfiah teks, maka publik mempunyai otoritas untuk mengedit, menyempumakan dan memodifikasi ketentuan tersebut. Contohnya terhadap ayat hldud, qisas' dan waris misalnya dapat "dikoreksi" melalui prosedur tanqihyang berupa taquidbi al-'aql (pembatasan dengan akal), takhsis di al-'ad (pengkhususan dengan akal) dan tabjiabi al-'ad (penjelasan dengan akal), dengan alasan ayatayat tentang hal tersebut (hlddud, waris, 'uqubatdan sebagainya) termasuk kategori ayat fussliksehingga meungkinkan untuk ditaquid, ditakhsis/dan ditabjin dengan akal.
} 
konvensional, partiarkhal, bias gender, eksklusif, cenderung berpihak pada ideologi mainđtream dan sangat "berbau" Arab.

Dalam konteks demikian, ijtihad kalangan post-tradisionalisme Islam mesti disikapi dengan arif. Apa yang dicobatawarkan kalangan post-tradisionalisme Islam, merupakan "vitamin" yang dapat meningkatkan kadar dinamika pemikiran Islam yang hingga tahapan tertentu telah mengalami stagnasi, sehingga akhirnya pemikiran-pemikiran mereka yang terkadang "subversif" itu tidak disikapi dengan bantahan secara apologis, apalagi sampai dengan "menuding kafir dan halal darahnya." Jika terakhir ini yang terjadi, maka akan terjadi proses pemiskinan dan akhirnya stagnasi intelektual.

Pada sisi lain, kritik-kritik ${ }^{33}$ terhadap pemikiran post-tradisionalisme Islam, meskipun disikapi secara bijak oleh kalangan post-tradisionalisme Islam sendiri melalui semangat untuk secara continas, mengkritisi kembali produk pemikirannya sendiri (saf citiosm) baik yang berkaitan dengan tafsir atas teks suci, tradisi ataupun ideologi berdasarkan pada nilai-nilai etis yang telah diperolehnya setelah bergumul dengan berbagai tradisi keilmuan dan dinamika kehidupan sosial yang terus berubah, sehingga produk-produk pemikirannya tetap mengabdi kepada kepentingan kemanusiaan sesuai dengan perkembangan konteks situasionalnya.

Implikasinya adalah, sesuai dengan karakter dasarnya, pemikiran post-tradisionalisme Islam tidak akan pernah mengenal finalisasi melainkan terus bergulir seiring dengan bergulirnya waktu. Semangat demikian, jika ditubuhkan pada struktur dan muatan kurikulum pendidikan agama Islam, jelas senantiasa memerlukan restrukturisasi, dekonstruksi-rekonstruksi paradigma maupun muatannya sesuai dengan dinamika situasi yang berkembang.

D alam konteks demikian, kalangan post-tradisionalisme Islam mesti; petama, intensif dan ekstensif dalam membedah produk dan konstruksi pemikiran Islam dengan berusaha melakukan apa yang disebut sebagai embedment, disembedment dan reembedment terhadap pemikiran Islam, kedua, mereka mesti menyadari bahwa seberapapun canggihnya suatu produk pemikiran pasti memiliki kelemahan, sehingga dengan semangat demikian, senantiasa terjadi proses reativisme intemal, dan tidak menganggap produk pemikiran sendiri sebagai yang terbaik. Artinya, sedari awal mesti ditanamkan heterogenitas produk pemikiran guna menghindari terbentuknya sikap monolitik.

\section{Daftar Rujukan:}

Arkoun, Mohammed. "Kritik Konsep Reformasi Islam," dalam Abdullahi Ahmed an-Na'im et al., Dekonstruksi Syaan'ah II: Kritik Konsep dan Perjdajahan Lain, terj. Farid Wajidi. Yogyakarta: LKiS, 1996.

Azra, Azyumardi. "Mengkaji Ulang Modernisme Muhammadiyah," Kompes, 9 Nopember 1990.

${ }^{33}$ Misalnya kritik dari Ulil Abshar Abdalla yang menyatakan bahwa munculnya komunitas post-tradisionalisme Islam merupakan kegagalan anak-anak muda NU berdialog dengan realitas di luarnya, kecewa dan cemburu dengan komunitas lain. Post Tradisionalisme Islam, dalam pandangan Ulil, merupakan metode lebih canggih untuk melestarikan konflik PMII versus HMI, NU versus Muhammadiyah, modernis versus tradisionalis. Posttradisionalisme Islam lebih sebagai upaya untuk mempertegas identitas kelompok daripada untuk mengembangkan wacana pemikiran. Robin L. Bush dalam disertasinya mengemukakan hal sama bahwa post tradisionalisme Islam tidak lebih sebagai pelestarian konflik tradisionalis-modemis dengan "baju baru." 
Baso, Ahmad. "Pengantar penerjemah: Post Tradisionalisme sebagai Kritik Islam: Kontribusi Metodologis Kritik Nalar Muhammed Abed al-Jabiri," dalam Muhammad Abed alJabiri, Post Tradisionalisme Isam Yogyakarta: LKiS, 2000.

Barton, G reg. Gagasan IslamLiberal d Indonesia: Pemikiran NeoModkmismeNurchdish Madid, Djohan Effendi, Ahmad Wahib dan Abdurrahman Wăhid, terj. Nanang Tahqiq. Jakarta: Paramadina, 1999.

Booklet. "Madrasah Emansipatoris: Agama, Gender dan Kebudayaan," Desantara Institute for Cultural Studies, 2002.

D hofier, Zamakhsyari. Tradis Pesantren Studi tetang Pandangan Hidup Kyai. Jakarta: LP3E S, 1982.

Kurnia, Nia dan Amelia Fauzia. "Gerakan Modernisme," dalam ed. Taufik Abdullah et al., Ensiklqpedi Tematis Dunia Isam(Asia Tenggara), jil. 5. Jakarta: Ichtiar Baru Van Hoeve, 2003.

Rahman, Fazlur. NeoModamisme Islam Metode dan Alternatif, ed. Taufik Adnan Amal. Bandung: Mizan, 1989.

Rahmat, Imdadun. "Islam Pribumi: Mencari Wajah Islam Indonesia," Tashininl Afkar, No. 14 (2003).

Rumadi. Post Tradisianalisme Idam Wacana IntddktualismedalamKammitas NU. Jakarta: Ditjen Diktis, 2007.

Siradj, Said Aqiel. "Latar Kultural dan Politik Kelahiran Aswaja," dalam ed. Imam Baehaqi, Kontrovesi Asnaja: Aula Perdbatan dan Renterpreasi. Yogyakarta: LKiS, 2000.

Susanto, Edi. "Postmodernisme: Kritik atas Meta NarrativeE pistemologi Modernisme," alAfkar: Jumal Dialogis IlmtIlmu Ushuluddin No. 8 (Juli-D esember 2003).

Zada, Khamani. "Mencari Wajah Post Tradisionalisme Islam," Tashininl Afkar, No. 9 (2000). 